\title{
Pelaksanaan Eksekusi Pembayaran Uang Pengganti Terhadap Putusan Pengadilan Dalam Perkara Tindak Pidana Korupsi Pada Kejaksaan Negeri Kuala Tungkal
}

\author{
Kabib Nawawi, Andi Najemi \\ Fakultas Hukum Universitas Jambi, Indonesia
}

\begin{abstract}
ABSTRAK
Dasar pemikiran penelitian ini adalah bahwa pidana tambahan uang pengganti dalam tindak pidana korupsi acapkali merupakan problematik yang secara faktual mempunyai daya tarik tersendiri, mengingat sulitnya untuk menarik kembali kerugian Negara sebagai akibat dari tindak pidana korupsi terhadap pelaksanaan eksekusi pembayaran uang pengganti terhadap keputusan hakim yang telah mempunyai kekuatan hukum tetap sebagaimana yang ditentukan di dalam Undang-undang Nomor 31 Tahun 1999 jo. Undang-undang Nomor 20 Tahun 2001 Jo Peraturan Mahkamah Agung Nomor 5 Tahun 2014 tentang Pidana Tambahan Uang Pengganti Tindak Pidana korupsi. Tipe penelitian ini adalah penelitian Yuridis Empiris. Penggunaan Tipe/pendekatan penelitian ini dimaksud untuk memperoleh gambaran satu masalah yaitu peranan kejaksaan sebagai eksekutor dalam upaya pengembalian kerugian negara melalui penarikan uang pengganti atas dasar putusan pengadilan terhadap perkara tindak pidana korupsi yang telah mempunyai kekuatan hukum tetap. Spesifikasi penelitian yang digunakan adalah penelitian hukum deskriptif guna memperoleh gambaran satu masalah yaitu pelaksanaan eksekusi pembayaran uang pengganti oleh Kejaksaan Negeri Kuala Tungkal terhadap putusan pengadilan yang telah mempunyai kekuatan hukum tetap, sebagai upaya pengembalian kerugian Negara, disamping itu dilakukan wawancara dengan pihak dari Kejaksaan untuk menjawab tentang pelaksanaan eksekusi tersebut. Pengumpulan data yang digunakan adalah data primer dan data sekunder Teknik penentuan sampel penelitian dengan metode non random purposive sampling (sampel bertujuan) dengan menetapkan langsung para responden penelitian yaitu: Kasi Pidsus pada Kejaksaan Negeri Kuala Tungkal. Adapun hasil penelitian adalah bahwa pelaksanaan eksekusi pembayaran sanksi pidana pembayaran uang pengganti belum terlaksana dengan baik, hal ini terjadi karena sulitnya mengidentifikasi barang yang mau disita untuk di lelang yang mekanismenyapun tidak mudah.
\end{abstract}

Kata Kunci: Eksekusi, Uang Pengganti, Tindak Pidana Korupsi

\section{PENDAHULUAN}

Tindak Pidana Korupsi sebagaimana yang diatur di dalam Undang-Undang Nomor 31 Tahun 1999 Tentang Pemberantasan Tindak Pidana Korupsi, jo. Undang-Undang Nomor 20 Tahun 2001 tentang perubahan atas undang-undang nomor 31 tahun 1999 tentang pemberantasan tindak pidana korupsi bertujuan untuk menjamin kepastian hukum terhadap pengembalian kerugian keuangan negara sebagai akibat tindak pidana korupsi. Oleh sebab itu sebagai jaminan terhadap pembayaran uang pengganti terhadap keputusan hakim yang telah mempunyai kekuatan hukum tetap, maka harus di laksanakan melalui mekanisme yang telah di. tetapkan oleh undang-undang.

Berdasarkan kajian terhadap Risalah Rapat Undang - Undang No. 31 Tahun 1999 dan ditopang oleh teori yang bersifat tafsiran doktriner terhadap pidana uang pengganti, maka ditetapkannya pidana uang pengganti dalam Undang - Undang No. 31 Tahun 1999 merupakan suatu mekanisme pemidanaan yang dimaksudkan untuk memulihkan keseimbangan yang 
terganggu akibat suatu tindak pidana, agar suatu pidana dan pemidanaan menjadi efektif yang bertujuan untuk mengembalikan kerugian negara yang hilang akibat tindak pidana korupsi. ${ }^{1}$

Kalau diperhatikan di dalam Undang-undang No. 31 tahun 1999 Juncto Undangundang Nomor 20 Tahun 2001, terdapat adanya penyimpangan dari hukum acara pidana sebagaimana yang telah ditentukan di dalam Undang-Undang Nomor 8 Tahun 1981 tentang Kitab Undang-Undang Hukum Acara Pidana (KUHAP). Penyimpangan tersebut justru dimaksudkan untuk memberikan kemudahan-kemudahan di dalam proses pembuktian dan pemeriksaan perkara tindak pidana korupsi (Lex Spesialis) .

Sanksi pidana pembayaran uang pengganti dalam perkara korupsi mengandung banyak permasalahan, diantaranya belum mencapai kesempurnaan tentang seperangkat peraturan yang menyertai persoalan ini. Salah satunya adalah penerapan pada Undang-undang No. 20 tahun 2001 tersebut masih terkendala karena kurang lengkap dan tegas dalam pengaturan tata cara pengadilan tindak pidana korupsi dalam hal pengembalian uang Negara yang dikorupsi ${ }^{2}$

Untuk mengatasi permasalahan tersebut pemerintah melalui Mahkamah Agung Republik Indonesia telah mengeluarkan peraturan teknis pelaksanaan pidana pembayaran uang pengganti yaitu Surat Edaran Mahkamah Agung Nomor 5 Tahun 2014 yang mengatur pidana tambahan uang Pengganti Tindak Pidana Korupsi. Dalam Pasal 1 disebutkan bahwa "dalam hal menentukan pembayaran uang pengganti dalam tindak pidana korupsi, sebanyakbanyaknya sama dengan harta benda yang diperoleh dari korupsi, dan bukan semata-mata sejumlah kerugian Negara yang diakibatkan".

Oleh karena itu persoalannya yang sering muncul adalah bahwa keberadaan pidana tambahan berupa kewajiban membayar uang pengganti bagi terpidana korupsi dinilai berjalan kurang efektif. karena terpidana banyak yang memilih hukuman pengganti berupa kurungan badan dibandingkan harus membayar uang pengganti.

Mengingat bahwa pengganti tidak sepenuhnya dapat ditagih kepada si terpidana korupsi, sehingga terhadap si terpidana di subsider dengan hukuman badan berupa penjara untuk mengganti kekurangan dari uang pengganti yang tidak dapat dibayarkan. Artinya pelaksanaan hukuman subsider badan tetap tidak dapat memulihkan kerugian Negara sehingga tujuan pokok undang-undang pemberantasan tindak pidana korupsi tidak dapat tercapai.

Pelaksanaan putusan pidana pembayaran uang pengganti tersebut dilakukan oleh kejaksaan selaku aparat eksekusi. Sebagaimana yang di tentukan di dalam Pasal 270 KUHAP, yaitu "Pelaksanaan putusan pengadilan yang telah mempunyai kekuatan hukum tetap dilakukan oleh Jaksa, yang untuk itu panitera mengirimkan salinan surat putusan kepadanya" Sebagai pelaksana eksekusi jaksa berkewajiban untuk menjalankan putusan pengadilan, Namun masalahnya adalah apakah putusan pengadilan tersebut dapat dengan segera dilaksanakan oleh kejaksaan. Mengingat dalam kasus korupsi barang-barang bukti kadang sulit untuk diidentifikasi, sehingga dalam pelaksanaannya akan ada kendala atau masalah yang akan ditemui dalam hal pelaksanaan putusan tersebut, khususnya putusan pidana uang pengganti yang wajib dibayar oleh terpidana kasus korupsi.

Pada dasarnya pelaksanaan putusan pembayaran uang pengganti dilakukan melalui mekanisme beberapa tahapan sebagai berikut:

1. Tahap penagihan.

2. Tahap pembayaran uang pengganti.

3.. Tahap pelelangan

1 Rizkisyah Karoen Nasution dkk, Jurnal Permasalahan Pidana Uang Pengganti Terkait Teori Pemidanaan, Berdasarkan Undang - Undang Nomor 31 Tahun 1999 tentang Pemberantasan Tindak Pidana Korupsi. Hal 8 2012, hal. 143

${ }^{2}$ Wiyono, Pembahasan Undang-undang Pemberantasan Tindak Pidana Korupsi, Sinar Grafika, Jakarta, 


\section{Tahap gugatan perdata}

Konsep pembayaran uang pengganti adalah untuk membuat jera pelaku korupsi tidak menikmati hasil kejahatannya dan negara dapat memperoleh pengembalian uang yang diderita. Pendapat tersebut di atas didasarkan pada kenyataan dalam praktik bahwa dari banyaknya pelaksanaan eksekusi perkara tindak pidana korupsi yang ditangani oleh jaksa sangat sulit ditemukan hasil tindak pidana korupsi dari pelaku tindak pidana korupsi

Paparan di atas adalah merupakan isu sentral dalam penelitian ini, sehingga secara khusus sesuai dengan kajian dan analisis berbagai peraturan yang mengatur tentang pidana tambahan pembayaran uang pengganti dan berbagai sember, ternyata pelaksanaan eksekusi pidana pembayaran uang penggait mekanismenya di mungkinkan akan mengalami kesulitan secara faktual.

Secara faktual Putusan Pengadilan Negeri Tipikor Jambi dan putusan Mahkamah Agung Republik Indonesia pada tahun 2016 s/d Tahun 2018 terdapat putusan perkara korupsi yang telah memperoleh kekuatan hukum tetap, dimana dalam putusan pengadilan tersebut telah ditentukan pidana tambahan dalam bentuk pembayaran uang pengganti yang jumlahnya berfariasi, sebagaimana terlihat pada tabel berikut:

Tabel 1. Jumlah Perkara Tindak Pidana Korupsi Yang Telah Mempunyai Kekuatan Hukum Tetap Pada Kantor Kejaksaan Negeri Kuala Tungkal Tahun 2016 s/d Tahun 2018

\begin{tabular}{|c|c|c|c|c|}
\hline TAHUN & & NOMOR PERKARA & $\begin{array}{l}\text { JUMLAH UANG } \\
\text { PENGGANTI }\end{array}$ & $\begin{array}{l}\text { TANGGAL } \\
\text { PUTUSAN }\end{array}$ \\
\hline \multirow{3}{*}{2016} & 1 & $\begin{array}{c}\text { PDS-01/Ft.1/06/2016 } \\
\text { 21/PID-SUS-TPK/2015/PN.JMB } \\
\text { An, Rustam Efendi, S.H }\end{array}$ & 59.954 .000 & 4 Januari 2016 \\
\hline & 2 & $\begin{array}{l}\text { PDS-01/Ft.1KTKL/09/2013 } \\
\text { 144 PK.PID-SUS /2014 (MA) } \\
\text { An. NANO KUSHARYONO }\end{array}$ & 2.470 .000 .000 & 26 NOVEMBER 2014 \\
\hline & 3 & $\begin{array}{l}\text { PDS-01/Ft.1/KTKL/2013 } \\
\text { 1630.K/PID.SUS/2014 (MA) } \\
\text { An. Samhuri S.H }\end{array}$ & 265.582.000 & 26 NOVEMBER 2014 \\
\hline 2017 & & NIHIL & $=$ & $=$ \\
\hline \multirow[t]{2}{*}{2018} & 1 & $\begin{array}{l}\text { PDS-01/Ft.1/KTKL/01/2018 } \\
\text { 35/PID SUS-TPK/2017/PN JMB } \\
\text { An. Abdul Halim Gumri }\end{array}$ & 431.822 .986 & 07 FEBRUARI 2018 \\
\hline & 2 & $\begin{array}{c}\text { PDS-01/Ft.1/KTKL/01/2018 } \\
\text { 07/PID.SUS-TPK/2018/PN-JMB } \\
\text { An . Zamzami, S.H }\end{array}$ & 10.518379 & 24 Mei 2018 \\
\hline
\end{tabular}

Sumber: Data hasil penelitian Pada Kantor Kejaksaan Negeri Kuala Tungkal tanggal 27 Februari 2018

Pada tabel di atas, bahwa dalam kasus tindak pidana korupsi di Kabupaten Tanjung Jabung Barat yang menjadi wilayah kompetensi Kejaksaan Negeri Kuala Tungkal tahun 2016 ada 3 kasus dan tahun 2018 ada 2 kasus dengan jumlah sanksi pidana pembayaran uang pengganti sebesar Rp 3.237.877.365,- (Tiga milyar dua ratus tiga puluh tujuh delapan ratus tujuh puluh tujuh ribu tiga ratus enam puluh lima rupiah).

Meskipun pidana tambahan dalam bentuk pembayaran uang pengganti, sedemikian tegas ditentukan di dalam undang-undang, apakah kemudian oleh jaksa pada Kejaksaan Negeri Kuala Tingkal selaku eksekutor dapat mengimplementasikan dengan baik ketika putusan pengadilan telah memperoleh kekuatan hukum tetap eksekusi terhadap pembayaran uang pengganti tersebut dilaksanakan, apakah telah terlaksana secara maksimal sebagaimanaa yang 
telah dituangkan di dalam keputusan hakim?. Untuk menjawab semua pertanyaan di atas, kiranya perlu dilakukan penelitian untuk mengetahui pelaksanaan eksekusi pembayaran uang pengganti sebagai pidana tambahan dalam perkara tindak pidana di Kejaksaan Negeri Kuala Tungkal

\section{METODE PENELITIAN}

\section{Tipe Penelitian}

Tipe penelitian yang digunakan adalah penelitian Yuridis Empiris. Penggunaan Tipe / pendekatan penelitian ini dimaksud untuk memperoleh gambaran satu masalah yaitu peranan kejaksaan sebagai eksekutor dalam upaya pengembalian kerugian negara melalui penarikan uang pengganti atas dasar putusan pengadilam terhadap perkara tindak pidana korupsi.

\section{Spesifikasi penelitian}

Spesifikasi penelitian yang dilakukan dalam penelitian ini adalah penelitian hukum deskriptif guna memperoleh gambaran satu masalah yaitu pelaksanaan eksekusi pembayaran uang pengganti oleh Kejaksaan Negeri Kuala Tungkal terhadap putusan pengadilan yang telah mempunyai kekuatan hukum tetap, sebagai upaya pengembalian kerugian negara disamping itu dilakukan wawancara dengan pihak dari Kejaksaan untuk menjawab tentang pelaksanaan eksekusi tersebut.

\section{Teknik pengumpulan data}

Data yang dibutuhkan dan dipergunakan dalam penelitian ini adalah data primer dan data sekunder

a. Data primer yaitu data yang diperoleh langsung dari obyek penelitian lapangan dengan menggunakan metode yang telah ditentukan. Data yang dimaksud berupa informasi dari responden mengenai Pelaksanaan putusan Pengadilan Negeri Kuala Tungkal yang telah mempunyai kekuatan hukum tetap terhadap pembayaran uang pengganti dalam tindak pidana korupsi

b. Data sekunder, data yang diperoleh dari studi pustaka yaitu dengan mempelajari ilmu pengetahuan hukum serta peraturan yang berlaku yang berkaitan dengan permasalahan, yaitu berupa:

a). Data sekunder bahan hukum primer berupa :

Undang-Undang Nomor 8 Tahun 1981 tentang Kitab Undang - Undang Hukum Acara Pidana ( KUHAP ). Undang-Undang Nomor 31 Tahun 1999 Tentang Pemberantasn Tindak Pidana Korupsi Jo Undang-Undang Nomor 20 Tahun 2001 Tentang Perubahan Undang-Undang Nomor 31 Tahun 1999 Tentang Pemberantasn Tindak Pidana Korupsi.

b). Data sekunder bahan hukum sekunder berupa : Peraturan Pemerintah, Instruksi Menteri sebagai peraturan yang menjabarkan lebih lanjut dari bahan hukum primer.

c). Data sekunder dari bahan hukum tersier berupa bahan yang didapat dalam literaturliteratur, pendapat pakar, hasil penelitian, kamus, jurnal media massa dari surat kabar maupun majalah.

Data primer diperoleh melalui responden. Responden yang dipilih ditetapkan dengan metode non random purposive sampling (sampel bertujuan) dengan menetapkan langsung para responden penelitian yaitu :

a. Kasi Pidsus pada Kejakanaan Negeri Kuala Tungkal

b. Satu orang Jaksa fungsional pada Kejaksaan Negeri Kuala Tungkal 


\section{Pengolahan dan analisis data}

Data yang diperoleh berupa data primer maupun data sekunder dikumpulkan, disusun, dijelaskan dan dianalisis secara kualitatif, kemudian diuraikan dan dibahas dengan menggunakan metode deskriptif analitis. Hasil metode deskriptif analitis diharapkan dapat menjawab terhadap permasalahan yang diteliti.

\section{PEMBAHASAN HASIL PENELITIAN}

\section{Pelaksanaan Eksekusi Pembayaran Uang Pengganti}

Instrumen yang mendasar dalam kajian hukum pidana salah satunya adalah terletak pada sanksi pidana yang di ancamkan pada tindak pidana tersebut. Bahkan tidak berlebihan kalau dikatakan bahwa hukum pidana tanpa sanksi pidana bukanlah norma hukum pidana, atau dengan kata lain bahwa dikatakan norma hukum pidana karena adanya sanksi pidana yang melekat pada norma tersebut, sehingga dapat dikatakan bahwa sanksi pidana merupakan syarat mutlak terhadap norma hukum pidana. Pidana (pemidanaan) merupakan komponen paling mendasar dalam kajian hukum pidana, Itulah sebabnya seringkali dinamakan hukum pidana sebagai hukum sanksi yang istimewa. Menurut Sudarto, sejarah hukum pidana pada hakekatnya yang hakiki adalah sejarah dari (sanksi) pidana dan pemidanaan itu sendiri. Sanksi Pidana yang termasuk juga di dalamnya tindakan (maatregel,masznahme), bagaimanapun merupakan suatu penderitaan atau suatu rasa tidak enak oleh yang dikenai. Oleh karena itu orang tidak henti hentinya untuk mencari dasar, hakekat dan tujuan pidana dan pemidanaan, untuk memberikan alasan pembenar dari pidana itu. ${ }^{3}$ Demikian juga seharusnya di dalam Undang - Undang Nomor 31 Tahun 1999 tentang Pemberantasan Tindak Pidana Korupsi, tujuan dan teori pemidanaan tetap hidup di dalamnya. Terlebih bagi Negara Indonesia sebagai Negara berkembang yang sedang berupaya aktif untuk memberantas korupsi, pendekatan hukum pidana sebagai salah satu instrumen dalam memerangi korupsi masih menjadi pilihan utama, sehingga dalam usahanya memberantas korupsi diperlukan jenis pemidanaan yang tepat dengan tujuan dan teori pemidanaan yang sesuai dengan tujuan pemberantasan tindak pidana korupsi, Undang-Undang No. 31 Tahun 1999 tentang Pemberantasan Tindak Pidana Korupsi yang memiliki misi untuk mengembalikan uang negara. Dimana selain dibekali dengan ancaman pidana pokok penjara dan denda dengan minimum khusus. UU No. 31 Tahun 1999 juga dibekali dengan pidana tambahan, hal ini seperti yang diatur dalam Pasal 17 jo. Pasal 18 UU No. 31 Tahun 1999 yang menyatakan bahwa selain dapat dijatuhi pidana pokok, terdakwa dalam perkara korupsi dapat dijatuhi pidana tambahan, dimana salah satu bentuknya adalah pidana uang pengganti.

Sebab dengan rumusan sanksi pidana pembayaran uang pengganti sebagaimana yang diatur dalam pasal 18 Undang-undang Nomor 31 tahun 1999, jo. Undang-undang Nomor 20 tahun 2001, sebagai pidana tambahan, maka akibatnya hakim dalam mengambil keputusan tidak terikat dengan rumusan sanksi pidana uang pengganti, dan di dalam praktek ternyata banyak keputusan hakim terhadap tindak pidana korupsi tidak memasukan pidana uang pengganti sebagai sanksi pidana kumulatif. Kalau pidana pembayaran uang pengganti dijatuhkan dalam putusan hakim, selalu dibarengi dengan pidana penjara sebagai alternatif kalau sanksi pidana pembayaran uang pengganti tidak di bayar, dan acapkali lamanya pidana penjara sebagai alternatif pidana pembayaran uang pengganti lamanya kurang dari satu tahun.

Khusus di wilayah hukum Kejaksaan Negeri Kuala Tungkal dalam 3 (tiga) tahun terakhir terdapat putusan hakim terhadap tindak pidana korupsi yang telah mempunyai kekuatan hukum tetap sebagaimana terlihat pada tabel berikut:

${ }^{3}$ Sudarto, Hukum dan Hukum Pidana, (Bandung: Alumni, 1981), hal. 30 
Tabel 2. Jumlah Perkara Tindak Pidana Korupsi Yang Telah Mempunyai Kekuatan Hukum Tetap Pada Kantor Kejaksaan Negeri Kuala Tungkal Tahun 2016 s/d Tahun 2018

\begin{tabular}{|c|c|c|c|c|}
\hline TAHUN & \multicolumn{2}{|r|}{ NOMOR PERKARA } & \multirow{2}{*}{$\begin{array}{c}\text { JUMLAH UANG } \\
\text { PENGGANTI } \\
\text { RP } \\
59.954 .000\end{array}$} & \multirow{2}{*}{$\begin{array}{l}\text { TANGGAL } \\
\text { PUTUSAN } \\
\text { 4 Januari } 2016\end{array}$} \\
\hline \multirow{3}{*}{2016} & 1 & $\begin{array}{c}\text { PDS-01/Ft.1/06/2016 } \\
\text { 21/PID-SUS-TPK/2015/PN.JMB } \\
\text { An, Rustam Efendi, S.H }\end{array}$ & & \\
\hline & 2 & $\begin{array}{l}\text { PDS-01/Ft.1KTKL/09/2013 } \\
144 \text { PK.PID-SUS /2016 (MA) } \\
\text { An. NANO KUSHARYONO }\end{array}$ & 2.470 .000 .000 & 26 November 2016 \\
\hline & 3 & $\begin{array}{c}\text { PDS-01/Ft.1/KTKL/2013 } \\
\text { 1630.K/PID.SUS/2016 (MA) } \\
\text { An. Samhuri S.H }\end{array}$ & 265.582 .000 & 26 November 2016 \\
\hline 2017 & & NIHIL & $=$ & $=$ \\
\hline \multirow{2}{*}{2018} & 1 & $\begin{array}{c}\text { PDS-01/Ft.1/KTKL/01/2018 } \\
\text { 35/PID SUS-TPK/2017/PN JMB } \\
\text { An. Abdul Halim Gumri }\end{array}$ & 431.822 .986 & 07 Februari 2018 \\
\hline & 2 & $\begin{array}{c}\text { PDS-01/Ft.1/KTKL/01/2018 } \\
\text { 07/PID.SUS-TPK/2018/PN-JMB } \\
\text { An . Zamzami, S.H }\end{array}$ & 10.518379 & 24 Mei 2018 \\
\hline
\end{tabular}

Sumber: Data hasil penelitian Pada Kantor Kejaksaan Negeri Kuala Tungkal tanggal 27 Februari 2018

Dari tabel di atas terlihat bahwa terhadap semua perkara tindak pidana korupsi yang terjadi di Wilayah Kabupaten Tanjung Jabung Barat terdapat 5 perkara yang telah diputus oleh hakim dan telah mempunyai kekuatan hukum tetap, yaitu tahun 2016 ada 3 kasus dan tahun 2018 ada 2 kasus. Sedangkan tahun 2017 nihil atau tidak ada perkara tindak pidana korupsi.

Dari 5 (lima) kasus tindak pidana korupsi tahun 2016 dan tahun 2018, semuanya telah dijatuhkan pidana pembayaran uang pengganti dengan kerugian Negara secara keseluruhan berjumlah Rp 3.237.877.365,- (Tiga milyar dua ratus tiga puluh tujuh delapan ratus tujuh puluh tujuh ribu tiga ratus enam puluh lima rupiah). Oleh karena itu mengingat bahwa putusan tersebut sudah mempunyai kekuatan hukum tetap, maka keputusan tersebut harus segera dilaksanakan. Pelaksana putusan hakim yang telah mempunyai kekuatan hukum tetap dilaksanakan oleh jaksa sebagaimana yang diatur di dalam Pasal 270 KUHAP "pelaksanaan putusan pengadilan yang telah memperoleh kekuatan hukum tetap dilakukan oleh jaksa, yang untuk itu panitera mengirimkan salinan surat putusan kepadanya". Undang-Undang Nomor 31 Tahun 1999 tidak mengatur secara khusus terhadap pelaksanaan eksekusi putusan pengadilan yang sudah mempunyai kekuatan hukum tetap, namun di dalam undang-undang ini hanya mengatur tentang mekanisme serta waktu pelaksanaan pembayaran pidana uang pengganti, sebagaimana yang ditentukan di dalam pasal 18 ayat 2 dan ayat 3.

(2) Jika terpidana tidak membayar uang pengganti sebagaimana dimaksud dalam ayat (1) huruf b paling lama dalam waktu 1 (satu) bulan sesudah putusan pengadilan yang telah memperoleh kekuatan hukum tetap, maka harta bendanya dapat disita oleh jaksa dan dilelang untuk menutup uang pengganti tersebut.

(3) Dalam hal terpidana tidak mempunyai harta benda yang mencukupi untuk membayar uang pengganti sebagaimana dimaksud dalam ayat (1) huruf $b$, maka di pidana dengan pidana penjara yang lamanya tidak melebihi ancaman 
maksimum dari pidana pokoknya sesuai dengan ketentuan dalam undangundang ini dan lamanya pidana tersebut sudah ditentukan dalam putusan pengadilan

Masalahnya adalah bagaimana pelaksanaan eksekusi pembayaran uang pengganti pada kejaksaan Negeri Kuala Tungkal senilai Rp 3.237.877.365,- (Tiga milyar dua ratus tiga puluh tujuh delapan ratus tujuh puluh tujuh ribu tiga ratus enam puluh lima rupiah) tersebut.

Menurut Muh Maskuri SH, dalam pelaksanaan putusan tersebut melalui beberapa tahapan kegiatan yang dapat diuraikan sebagai berikut: 1 . Tahap penagihan. 2 . Tahap pembayaran uang pengganti. 3 Tahap pelelangan. 4.Tahap gugatan perdata. ${ }^{4}$

\section{Tahap penagihan}

Pada tahap penagihan pelaksanaan eksekusi dilakukan oleh jaksa setelah menerima salinan putusan dari panitera pada pengadilan tipikor Jambi, meskipun sesuai dengan ketentuan pasal 18 ayat (2) Undang Undang Nomor 31 Tahun 1999, pelaksanaan eksekusi putusan pengadilan paling lambat satu bulan setelah putusan tersebut mempunyai kekuatan hukum tetap.

Pelaksanaan eksekusi sanksi pidana pembayaran uang pengganti pada Kejaksaan Negeri Kuala ungkal, baru terealisasi Rp. 70.427 .329 atau sekitar 2,15\%,. Sedangkan 97,85 $\%$ atau Rp. 3.167.450.036,-. belum dapat terealisasi. Kondisi ini disebabkan oleh terdakwa yang tidak kooperatif terhadap pelaksanaan pembayaran sanksi pidana pembayaran uang pengganti ${ }^{5}$, sehingga pembayaran sanksi pidana uang pengganti tidak berjalan secara efektif. Menurut penyidik yang memeriksa perkara tersebut menyatakan bahwa untuk melaksanakan eksekusi pidana pembayaran uang pengganti dilakukan melalui prosedur sebagai berikut:

1) setelah kejaksaan menerima berkas putusan pengadilan, lankah selanjutnya adalah Kasi Pidsus meneruskan kepada Kasi Intelijen, selanjutnya kasi intelijen melakukan investigasi terhadap harta benda terpidana sebagaimana yang ditentukan sebagai barang bukti dalam berkas perkara yang diduga sebagai hasil tindak pidana korupsi;

2) apabila dari hasil investigasi dari kasi intelijen ditemukan harta benda yang diduga merupakan hasil dari tindak pidana korupsi, maka dicatat dalam berita acara tentang temuan jenis-jenis barang tersebut, selanjutnya diserahkan kepada Kasi Pidsus untuk di tindak lanjuti ${ }^{6}$;

Permasalahannya adalah tidak semua terpidana mempunyai harta benda yang dapat disita, sehingga dalam upaya untuk melaksanakan pembayaran pidana uang pengganti. Dengan demikian maka langkah selanjutnya yang dilakukan Jaksa eksekutor adalah "memerintahkan kepada terpidana untuk membuat surat pernyataan tidak mampu yang di keluarkan oleh perangkat Desa. Dengan kondisi demikian maka kepada terpidana tidak lagi dibebankan untuk membayar pidana uang pengganti"”.

Namun menurut Kasi Pidsus Pada Kejaksaan Negeri Kuala Tungkal dalam pelaksanaannya pengiriman surat penagihan sering terlambat. Hal ini terjadi karena keterlambatan pengiriman salinan putusan pengadilan dari kepaniteraan tipikor Jambi. Sehingga akibat keterlambatan tersebut juga akan berpengaruh terhadap keterlambatan pengiriman surat penagihan kepada terpidana. ${ }^{8}$

\footnotetext{
${ }^{4}$ Ibid

${ }^{5}$ Herry Susanto, S.H. Kasi Pidsus pada Kejaksaan Negeri Kuala Tungkal

${ }^{6}$ Aidil Jaksa Fungsional pada Kejaksaan Negeri Kuala Tungkal

${ }^{7}$ Herry Susanto, Log Cit

${ }^{8}$ Herry Susanto, S.H. Kasi Pidsus pada Kejaksaan Negeri Kuala Tungkal
} 


\section{Tahap pembayaran pidana uang pengganti}

Pembayaran pidana uang pengganti secara normatif jumlah yang harus dibayar oleh terpidana tipikor sesuai dengan jumlah sebanyak-banyaknya sama dengan harta benda yang diperoleh dari tindak pidana korupsi”. Hal ini sesuai dengan ketentuan yang diatur di dalam pasal 18 ayat (1) huruf $b$ "pembayaran uang pengganti yang jumlahnya sebanyak-banyaknya sama dengan harta benda yang diperoleh dari tindak pidana korupsi"

Peraturan Mahkamah Agung Republik Indonesia Nomor 5 Tahun 2014 Tentang Pidana Tambahan Uang Pengganti Tindak Pidana Korupsi tanggal 31 Desember 2014 dengan dasar pemikiran sebagaimana yang tertera dalam konsideran Peraturan Mahkamah Agung menyebutkan:

a. bahwa Pasal 18 ayat (1) huruf b Undang-Undang - Nomor 31 Tahun 1999 Sebagaimana telah diubah dengan Undang-Undang Nomor 20 Tahun 2001 tentang Pemberantasan Tindak Pidana Korupsi n mengatur adanya pembayaran uang pengganti sebagai salah satu pidana tambahan:

b. bahwa dalam undang-undang tersebut diatur juga ketentuan jika terpidana tidak membayar uang : pengganti paling lama dalam waktu 1 (satu) bulan sesudah putusan pengadilan. "yang telah memperoleh kekuatan hukum tetap, maka "harta bendanya dapat disita oleh jaksa dan dilelang untuk menutupi uang pengganti tersebut. Selain itu, apabila setelah harta tersebut dirampas namun nilainya tidak cukup untuk membayar "uang 3 pengganti, maka terpidana dipidana dengan pidana penjara yang lamanya tidak melebihi ancaman -Maksimum dari pidana pokoknya,

Peraturan Mahkamah Agung di atas, sebagai dasar operasional undang-undang nomor 31 tahun 1999 yang secara tegas menentukan jika terpidana tidak membayar uang pengganti paling lama dalam waktu 1 (satu) bulan sesudah putusan pengadilan. "yang telah memperoleh kekuatan hukum tetap, maka "harta bendanya dapat disita oleh jaksa dan dilelang untuk menutupi uang pengganti tersebut. Selain itu, apabila setelah harta tersebut dirampas namun nilainya tidak cukup untuk membayar "uang pengganti, maka terpidana dipidana dengan pidana penjara yang lamanya tidak melebihi ancaman maksimum dari pidana pokoknya.

Dalam pelaksanaan eksekusi sanksi pidana pembayaran uang pengganti pada Kejaksaan Negeri Kuala Tungkal belum terlaksana dengan baik, karena ternyata bagi terpidana yang tidak membayar sanksi pidana pembayaran uang pengganti sampai saat penelitian ini dilakukan belum dilakukan proses penyitaan (perampasan barang), khususnya pada Tahun 2016 dalam Perkara Nomor PDS-01/Ft.1KTKL/09/2013. Perkara Nomor 144 PK.PID-SUS 12014 (MA) An. NANO KUSHARYONO dengan jumlah Rp. 2.470.000.000 dan Perkara PDS-01/Ft.1/KTKL/2013 jo 1630.K/PID.SUS/2014 (MA) An. Samhuri S.H dengan jumlah Rp. 265.582.000 serta Tahun 2018 perkara PDS-01/Ft.1/KTKL/01/2018 35/PID SUSTPK/2017/PN JMB An. Abdul Halim Gumri jumlah Rp. 431.822.986.

Terdapat beberapa tindakan yang harus diakukan oleh jaksa eksekutor dalam proses pelaksaan lelang eksekusi, yaitu :

1. Pendataan dan pengumpulan terhadap barang yang disita sebagai barang bukti pada proses pemberkasan perkara, tentang jenis barang, kondisi barang, (terutama barangbarang bergrerak). Sedangkan terhadap barang tidak bergerak yang diperiksa adalah tentang kelengkapan administrasi status dan kepemilikan barang yang disita. Hal ini dilakukan setelah ada keputusan hakim yang menyatakan barang tersebut disita untuk negara.

2. Memberitahukan kepada Kantor Pelayanan Kekayaan Negara dan Lelang (KPKNL), dan KPKNL telebih dahulu membuat penafsiran harga dari masing-masing jenis barang yang akan di lelang.

3. Pengumuman lelang dilakukan secara terbuka untuk umum, 
4. Pelaksanaan lelang dilakukan secara terbuka secara online

Menurut Kasi Pidsus pada Kejaksaan Negeri Kuala Tungkal bahwa terdapat beberapa tindakan yang dilakukan untuk melakukan penyitaan dan pelelangan yaitu :

1) melakukan penyitaan terhadap harta benda milik terpidana berdasarkan hasil penelusuran dai Kasi intelijen.

2) Setelah dilakukan penyitaan, selanjutnya dilakukan pelelangan yang didahului dengan surat permohonan dari jaksa eksekusi kepada Kantor Pelayanan Kekayaan Negara dan Lelang, (KPKNL) ${ }^{9}$

Hal senada juga disampaikan oleh Kasi Pidsus yaitu:

"Penyitaan (perampasan barang) dilakukan dalam rangka persiapan pelaksanaan proses pelelangan, harus sesuai dengan mekanisme yang berlaku, dan ini memakan waktu relatif lama. Sehingga dalam perkara tahun 2016 dan tahun 2018 penyitaan dilaukan terhadap barang milik terpidana yang belum melakukan pembayaran sanksi pidana pembayaran uang pengganti" 10 .

Pertanyaannya adalah apakah pelaksanaan pembayaran uang pengganti pada kejaksaan negeri Kuala Tungkal telah dapat dilaksanakan sebagaimana yang di tentukan di dalam undangundang Nomor 31 tahun 1999 dan Peraturan Mahkamah Agung Nomor 5 Tahun 2014 ?

Dari beberapa kasus tindak pidana korupsi di Kabupaten Tanjung Jabung Barat yang merupakan yurisdiksi wilayah Kejaksaan Negeri Kuala Tungkal jumlah kerugian Negara untuk masing-masing terpidana bisa dilihat pada tabel berikut:

Tabel 3. Realisasi pembayaran pidana uang pengganti pada kasus tindak pidana korupsi pada Kejaksaan Negeri Kuala Tungkal Tahun 2016 dan Tahun 2018

\begin{tabular}{|c|c|c|c|c|}
\hline TAHUN & \multicolumn{2}{c|}{$\begin{array}{c}\text { JUMLAH PIDANA UANG } \\
\text { PENGGANTI } \\
\text { Rp }\end{array}$} & $\begin{array}{c}\text { JUMLAH } \\
\text { REALISASI } \\
\text { Rp }\end{array}$ & $\begin{array}{c}\text { JUMLAH YANG } \\
\text { BELUM DI BAYAR } \\
\text { Rp }\end{array}$ \\
\hline 2016 & 1 & 59.954 .000 & 59.954 .000 & - \\
\hline & 2 & 2.470 .000 .000 & - & 2.470 .000 .000 \\
\hline & 3 & 265.582 .000 & - & 265.582 .000 \\
\hline $\mathbf{2 0 1 7}$ & & NIHIL & $=$ & $=$ \\
\hline 2018 & 1 & 431.822 .986 & - & 431.822 .986 \\
\hline & 2 & 10.518379 & 10.518379 & - \\
\hline \multicolumn{2}{|c|}{ Jumlah } & 3.237 .877 .365 & 70.472 .329 & 3.167 .405 .036 \\
\hline
\end{tabular}

Memperhatikan keadaan tabel 2 di atas pelaksanaan eksekusi sanksi pidana pembayaran uang pengganti pada Kejaksaan Negeri Kuala ungkal, baru terealisasi Rp.70.427.329 atau sekitar 2,15\%,. Sedangkan 97,85 \% atau Rp. 3.167.450.036,-. belum dapat terealisasi. Kondisi ini disebabkan oleh terdakwa yang tidak kooperatif terhadap pelaksanaan pembayaran sanksi pidana pembayaran uang pengganti ${ }^{11}$, sehingga pembayaran sanksi pidana uang pengganti tidak berjalan secara efektif . sehingga langkah selanjutnya yang harus dilakukan oleh Jaksa dalam menyikapi kondisi demikian, seharusnya dengan melakukan upaya penyitaan dan pelelangan.

\section{Tahap penyitaan dan pelelangan}

Penyitaan (perampasan barang-barang) terhadap harta benda terpidana hasil tindak pidana korupsi adalah merupakan salah satu upaya yang harus dilakukan oleh jaksa selaku pejabat

\footnotetext{
${ }^{9}$ Aidil Jaksa Fungsional Kejaksaan Negeri Kuala Tungkal

${ }^{10}$ Herry Susanto, S.H. Kasi Pidsus pada Kejaksaan Negeri Kuala Tungkal

${ }^{11}$ Herry Susanto, S.H. Kasi Pidsus pada Kejaksaan Negeri Kuala Tungkal
} 
pelaksana eksekusi sanksi pidana pembayaran uang pengganti dalam tindak pidana korupsi. Hal ini harus dilakukan dalam rangka untuk memenuhi amanat Pasal 18 ayat (1) huruf a Undang-undang Nomor 31 Tahun 1999 jo. Undang-undang nomor 20 Tahun 2001 serta Pasal 9 Peraturan Mahkamah Agung Nomor 5 tahun 2014 tentang Pembayaran Uang Pengganti Dalam Tindak Pidana Korupsi.

Jaksa dalam melakukan penyitaan (perampasan barang-barang) harus memperhatikan ketentuan Pasal 18 ayat (1) huruf a Undang-undang Nomor 31 Tahun 1999 menegaskan bahwa "perampasan barang bergerak yang berwujud atau yang tidak berwujud atau barang tidak bergerak yang digunakan untuk atau yang diperoleh dari tindak pidana korupsi, termasuk perusahaan milik terpidana di mana tindak pidana korupsi dilakukan, begitu pula dari barang yang menggantikan barang-barang tersebut". Namun dalam pelaksanaan eksekusi sanksi pidana pembayaran uang pengganti pada Kejaksaan Negeri Kuala Tungkal belum terlaksana dengan baik, karena ternyata bagi terpidana yang tidak membayar sanksi pidana pembayaran uang pengganti sampai saat penelitian ini dilakukan belum dilakukan proses penyitaan (perampasan barang), khususnya pada Tahun 2016 dalam Perkara Nomor PDS01/Ft.1KTKL/09/2013

Nomor 144 PK.PID-SUS /2014 (MA) An. NANO KUSHARYONO dengan jumlah Rp. 2.470.000.000 dan Perkara PDS-01/Ft.1/KTKL/2013 jo 1630.K/PID.SUS/2014 (MA) An. Samhuri S.H dengan jumlah Rp. 265.582.000 serta Tahun 2018 perkara PDS01/Ft.1/KTKL/01/2018 35/PID SUS-TPK/2017/PN JMB An. Abdul Halim Gumri jumlah Rp. 431.822 .986$.

Menurut Kasi Pidsus pada Kejaksaan Negeri Kuala Tungkal bahwa:

"Penyitaan (perampasan barang) dilakukan dalam rangka persaiapan pelaksanaan proses pelelangan, harus sesuai dengan mekanisme yang berlaku, dan ini memakan waktu relatif lama. Sehingga dalam perkara tahun 2016 dan tahun 2018 penyitaan dilaukan terhadap barang milik terpidana yang belum melakukan pembayaran sanksi pidana pembayaran uang pengganti" 12 .

Mekanisme pelaksanaan lelang eksekusi barang bukti dan darang hasil sitaan tindak pidana korupsi harus sesuai dengan prosedur sebagaimana ketentuan yang diatur di dalam Peraturan Menteri Keuangan (PMK) Nomor 27/PMK.06/2017 tentang Petunjuk Pelaksanaan Lelang. Pasal 11 ayat (1) dan ayat (2) yaitu:

Pasal 11

(1) Penjual yang akan melakukan penjualan barang secara lelang melalui KPKNL, harus mengajukan surat permohonan lelang dengan disertai dokumen persyaratan lelang kepada Kepala KPKNL untuk meminta jadwal pelaksanaan lelang.

(2) Dalam hal Lelang Eksekusi Panitia Urusan Piutang Negara, permohonan lelang diajukan melalui nota dinas yang ditandatangani oleh Kepala Seksi Piutang Negara KPKNL dan disampaikan kepada Kepala KPKNL bersangkutan.

Khusus untuk penyitaan barang sebagai syarat pelaksanaan lelang terhadap barang tindak pidana korupsi pada Kejaksaan Negeri Kuala ungkal masih terdapat kendala, terutama mengenai obyek barang yang akan disita belum terdata dengan baik., demikian juga terhadap pelaksanaan lelang masih belum bisa dilaksanakan, karena terkendala dengan kepemilikan harta benda sehingga pelaksanaan eksekusi terhadap pembayaran sanksi pidana pembayaran uang pengganti belum dapat optimal.

\footnotetext{
${ }^{12}$ Herry Susanto, S.H. Kasi Pidsus pada Kejaksaan Negeri Kuala Tungkal
} 


\section{Kendala Pelaksanaan Eksekusi Pembayaran Uang Pengganti}

Dalam kaitannya dengan pelaksanaan eksekusi pembayaran uang pengganti, maka kendala yang dimaksudkan menurut peneliti adalah halangan, rintangan, faktor yang menghalangi, pelaksanaan eksekusi pelaksanaan pembayaran pidana uang pengganti, khususnya di wilayah hukum yang menjadi kompetensi Kejaksaan Negeri Kuala Tungkal.

Pelaksanaan eksekusi terhadap pidana pembayaran uang pengganti terhadap pelaksanaan putusan hakim terhadap tindak pidana korupsi harus dilaksanakan dalam jangka waktu 1 (satu) bulan setelah putusan tersebut mempunyai kekuatan hukum tetap, sesuai amanah yang ditetapkan di dalam pasal 18 ayat (2) Undang-undang Nomor 31 Tahun 1999, yaitu: "Jika terpidana tidak membayar uang pengganti sebagaimana dimaksud dalam ayat (1) huruf b paling lama dalam waktu 1 (satu) bulan sesudah putusan pengadilan yang telah memperoleh kekuatan hukum tetap, maka harta bendanya dapat disita oleh jaksa dan dilelang untuk menutup uang pengganti tersebut".

Mengingat terdapat prosedur yang yang harus dilakukan untuk melaksanakan eksekusi waktunya sangat terbatas yaitu 1 (satu) bulan setelah putusan mempunyai kekuatan hukum tetap, maka sangat dimungkinkan putusan yang telah mempunyai kekuatan hukum tetap tersebut terdapat beberapa alternatif yaitu:

1. Putusan pengadilan pada tingkat pertama (Pengadilan Negeri)

1. Putusan pengadilan pada tingkat banding (Pengadilan Tinggi)

2. Putusan pada tingkat kasasi (Mahkamah Agung)

Dari 3(tiga) jumlah putusan tahun 2016 terdapat 2 (dua) perkara/kasus yang merupakan putusan Mahkamah Agung yaitu putusan Nomor 144 PK.PID-SUS /2016 atas nama terpidana Nano Kushariyono 630.K/PID.SUS/2016 atas naa terpidana Samhuri. Sehingga dengan adanya proses kasasi yang memakan waktu relatif lama, merupakan salah satu faktor penghambat pelaksanaan eksekusi terhadap pelaksanaan eksekusi pembayaran uang pengganti. Faktor penghambat lainnya adalah terkait dengan penyitaan harta benda terpidana yang diduga diperoleh dari tindak pidana korupsi.

Adapun pelaksanaan eksekusi pembayaran uang pengganti terdapat beberapa tahapan, antara lain yaitu 1 penagihan, 2. penyitaan harta benda milik terpidana yang diduga diperileh dari tindaak pidana korupsi, 3. pelelangan harta benda terpidana yang di dapat dari hasil penyitaan, dan 4. melalui gugatan perdata apabila hasil lelang tidak mencukupi untuk membayar pidana uang pengganti.

Hasil penelitian ternyata prosedur tahapan tersebut di atas tidak dapat terlaksana secara maksimal, khususnya pelaksanaan tahapan melalui gugatan perdata.menurut Aidil Raya Putera hal ini disebabkan "harta benda terpidana tidak ada yang dapat disita, karena bedasarkan laporan hasil penelusuran dari Kasi Intel terhambat dengan status kepemilikan harta benda yang bersangkutan, akibatnya kepada terpidana tidak lagi dibebani pembayaran pidana uang pengganti dengan alasan tidak mampu"13

Hal senada juga disampaikan oleh Kasi Hery Susanto, bahwa:

"terdapat 2 (dua) perkara yang tidak dapat melakukan pembayaran pidana uang pengganti karena dari hasil penelusuran dri Kasi Intel terhadap aset (asset tracing), tidak diketemukan harta benda yang dapat disita, dengan demikian kepada terpidana diminta untuk membuat pernyataan tidak mampu yang diketahui oleh perangkat desa guna untuk menentukan kebojakan berikutnya yaitu berupa pelaksanaan hukuman pidana penjara sebagai pidana subsider sebagaimana yang tertuang di dlam keputuan hakim"14

\footnotetext{
${ }^{13}$ Aidil Raya Putera, Jaksa Fungsional pada Kejaksaan Negeri Kuala Tungkal

${ }^{14}$ Hery Susanto, Kasi Pidsus d Kejaksaan Negeri Kuala Tungkal
} 


\section{KESIMPULAN DAN SARAN}

\section{Kesimpulan}

1. Pelaksanaan Eksekusi pembayaran uang pengganti terhadap perkara tindak pidana korupsi di Kejaksaan Negeri Kualam Tungkal belum terlaksana sebagaimana yang seharusnya. Hal ini terjadi karena ada beberapa faktor yaitu:

a) Secara prosedural karena ada keterlambatan terhadap berkas perkara putusan pengadilan yang sudah mempunyai kekuatan hukum tetap, sehingga berakibat terhadap proses pelaksanaan eksekusi;

b) Berdasarkan data putusan PN Tipikor Jambi serta Putusan Mahkamah Agung RI, dari tahun 2016 dan tahun 2018 terdapat 5 (lima) putusan yang telah mempunyai kekuatan hukum tetap. Dengan jumlah tagihan sebesar Rp 3.237.877.365,-- (Tiga milyar dua ratus tiga puluh tujuh delapan ratus tujuh puluh tujuh ribu tiga ratus enam puluh lima rupiah). , baru terealisasi Rp. 70.427.329 atau sekitar 2,15\%,. Sedangkan 97,85\% atau Rp. 3.167.450.036,-. belum dapat terealisasi, artinya harus dilakukan tindakan lain, yaitu dengan penyitaan dan pelelangan terhadap harta benda terpidana.

c) Tindakan penyitaan dan pelelangan tidak dapat dilaksanakan, karena berdasarkan hasil penelusuran dari kasi intelijen, bahwa tidak terdapat harta benda yang dapat disita, karena status kepemilikan harta benda bukan milik dari terdakwa.

\section{Saran}

Berdasarkan pembahasan di atas, yang sekaligus merupakan jawaban dari rumusan masalah dalam penelitian ini, maka untuk dirasa perlu untuk memberikan beberapa alternatif sebagai saran tindak lanjut pelaksanaan eksekusi pembayaran uang pengganti terhadap keputusan hakim yang telah mempunyai kekuatan hukum tetap, yaitu untuk memudahkan kejaksaan untuk melakukan identifikasi terhadap harta benda milik terpidana betul terdata dengan baik sejak proses penyidikan. Dengan demikian akan memudahkan pihak pelaksana eksekusi dalam penelusuran semua harta benda milik terpidana yang diduga dari tindak pidana korupsi

\section{DAFTAR PUSTAKA}

Artidjo Alkostar (vide: dalam Varia Peradilan, Majalah Hukum Ikatan Hakim Indonesia (IKAHI) Tahun XXIII Nomor 275 Oktober 2008

Arda Nawawi Arief, Beberapa Aspek Kebijakan Penegakan dan Pengembangan Hukum Pidana, Bandung : Citra Aditya Bakti, 1998, h. 69-70.

Dedyng Wibiyanto Atabay, "Pidana Tambahan Pembayaran Uang Pengganti Atas Kerugian Keuangan Negara Akibat Tindak Pidana Korupsi", (Tesis Magister Universitas Indonesia, Jakarta: 2005), h. 80

Djoko Prakoso, Ati Suryati, "Upetiisme Ditinjau dari Undang-undang Pemberantasan Tindak Pidana Korupsi”, Bina Aksara, 1986, h. 8

Leden Marpaung, "Tindak Pidana Korupsi Masalah dan Pemecahannya”, Sinar Grafika, 1992, h. ;62,

Rizkisyah Karoen Nasution dkk, Jurnal Permasalahan Pidana Uang Pengganti Terkait Teori Pemidanaan, Berdasarkan Undang - Undang Nomor 31 Tahun 1999 tentang Pemberantasan Tindak Pidana Korupsi. Hal 8

R Susilo,. Hukum Acara Pidana Prosedur Penyelesaian Perkara Pidana Bagi Penegak Hukum), Politeia, Bogor, 1977.

Syed Husein Alatas(,sebuah penjelajahan Dengan data Kontemporer)” LP3 ES, 1986,h. ll 
Yudi Wibowo Sukinto, :Konsep Baru Pengembalian Kerugian Negara Dari Tindak Pidana Korupsi” Yuridika Volume 31 No, 2, Mei-Agustus 2016 hal 343

Wiyono, Pembahasan Undang-undang Pemberantasan Tindak Pidana Korupsi, Sinar Grafika, Jakarta, 2012, hal. 143

\section{Undang-Undang:}

Undang-Undang Nomor 8 Tahun 1981 Tentang Kitab Undang-Undang Hukum Acara Pidana Undang-Undang No or 31 Tahu 1999, Tentang Pemberantasan Tindak Pidana Korupsi.

Undang-Undang Nomor 20 Tahun 2001 Tentang Perubahan atas Undang-Undang Nomor 31 Tahun 1999, Tentang Pemberantasan Tindak Pidana Korupsi

Undang-Undang Nomor 16 Tahun 2004 Tentang Kejaksaan

Peraturan Mahkamah Agung Nomor 5 Tahun 2014 Tentang Pidana Tambahan Uang Penggati Dalam Tindak Pidana Korupsi

Ungkap Terus Kasus Korupsi, http://www.pikiran-rakyat.com/cetak/2005/ 1205/27/01.htm 